\title{
HUBUNGAN PENYAKIT MENULAR BERBASIS LINGKUNGAN DENGAN STATUS GIZI BALITA
}

\author{
Elsa Elsi \\ Pusat Teknologi Intervensi Kesehatan Masyarakat \\ Elsa@litbang.depkes.go.id
}

\begin{abstract}
ABSTRAK
Penyakit menular berbasis lingkungan dapat menyebabkan kejadian gizi kurang dan gizi buruk. Penelitian lanjutan ini bertujuan untuk mengetahui hubungan antara penyakit menular berbasis lingkungan dengan status gizi balita (0-59 bulan) dengan menggunakan data Riskesdas 2007. Desain penelitian adalah crosssectional yang bersifat deskriptif. Populasi penelitian adalah seluruh balita $0-59$ bulan pada Riskesdas 2007, sedangkan sampel adalah seluruh balita $0-59$ bulan pada Riskesdas 2007 dengan ibu yang berusia 15-54 tahun. Kriteria inklusi adalah seluruh rumah tangga Riskesdas 2007 yang mempunyai balita dengan variabel yang lengkap. Data yang dikumpulkan meliputi: karakteristik balita (umur, jenis kelamin, berat badan), karakteristik ibu (umur, pendidikan, dan pekerjaan), penyakit menular berbasis lingkungan (penyakit filariasis, demam berdarah dengue, malaria, infeksi saluran pernafasan akut, pneumonia, tuberkulosis paru, campak, tifoid, hepatitis, diare), dan lingkungan rumah tangga balita (kualitas fisik air minum, kualitas tanah, dan pemeliharaan ternak). Hasil penelitian menunjukkan bahwa risiko status gizi kurang dan status gizi buruk pada balita yang mengalami penyakit menular berbasis lingkungan dan ibu dengan pendidikan SD ke bawah lebih tinggi $(O R=2,05)$ dibandingkan ibu dengan pendidikan perguruan tinggi $(O R=1,12)$. Sedangkan menurut tempat tinggal diketahui bahwa risiko status gizi kurang dan status gizi buruk pada balita yang mengalami penyakit menular berbasis lingkungan dan bertempat tinggal di perdesaan lebih tinggi $(O R=1,25)$ dibandingkan balita yang tinggal di perkotaan $(O R=1,12)$.
\end{abstract}

Kata kunci: penyakit menular, lingkungan, status gizi

\section{ABSTRACT}

\section{THE RELATIONSHIP BETWEEN COMMUNICABLE-DISEASE ENVIRONMENT-BASED AND NUTRITION STATUS OF CHILDREN UNDER FIVE YEARS}

Communicable disease on the basis of environment may lead to cause several disadvantages results including underweight and severe underweight. This advance analysis of Riskesdas 2007 data is aimed to test the relationship between environmental-based communicable disease and nutrition status among children under five years old (0-59 months). Riskesdas 2007 is the research in all basic health aspects of Indonesian, living in rural and urban all over Indonesia, run by Research and Development Board, Ministry of Health. This cross sectional desain was taken descriptively. The population are all the children aged 0.5 years old in Riskesdas 2007, and samples were those aged 0-5 years old with the mothers aged 15-54 years in Riskesdas 2007. Inclusion criteria is all riskesdas 2007's households who had complete all needed variables. Data analyzed were children under five's characteristics (age, sex, body weight), mothers' characteristics (age, education, and occupation), environmental-based communicable disease, such as filariasis, dengue, malaria, acute respiratory tract infection, pneumonia, pulmonary-tuberculosis, measles, thypoid fever, hepatitis, diarrhea), and households environment where children under five lived (physical quality of drinking water, soil quality, husbandry). Results indicates that the risk of underweight and severe underweight among children under five who experienced in enviromental-based communicable diseases and educational background of mothers with elementary school or below was higher $(O R=2.05)$ than those with tertiary education background $(O R=1.12)$. Whereas from residence, it has bveen tasted that the risk of children underfive who were underweight and severe underweight and infected by enviromental-based communicable disease and lived in rural had slightly higher (1.25) than those lived in urban $(\mathrm{OR}=1.12)$.

Key words: communicable disease, enviroment-based, nutrition status 


\section{PENDAHULUAN}

A rah kebijakan dan strategi Kementerian Kesehatan tahun 2010-2014, dititikberatkan pada pembangunan bidang kesehatan melalui pendekatan preventif, tidak hanya kuratif, melalui peningkatan kesehatan masyarakat dan lingkungan, di antaranya dengan perluasan penyediaan air bersih, pengurangan wilayah kumuh. Prioritas pembangunan kesehatan pada tahun 20102014 difokuskan pada delapan fokus prioritas, salah satunya adalah perbaikan status gizi masyarakat. ${ }^{1}$

Sebagaimana diketahui bahwa masalah gizi kurang dan terutama gizi buruk memiliki kontribusi terhadap kematian pada balita. Secara nasional prevalensi balita "gizi buruk dan kurang" menurun sebanyak 0,5 persen yaitu dari 18,4 persen pada tahun 2007 menjadi 17,9 persen pada tahun 2010.2,3. Setiap tahun lebih dari sepertiga kematian anak di dunia berkaitan dengan masalah gizi, yang dapat melemahkan daya tahan tubuh terhadap penyakit. ${ }^{4}$ Secara umum, defisiensi gizi sering merupakan awal dari gangguan sistim kekebalan. Gizi kurang dan infeksi, keduaduanya dapat bermula dari kemiskinan dan lingkungan yang tidak sehat dengan sanitasi yang buruk. ${ }^{5}$

Malnutrisi merupakan salah satu faktor penting yang berkontribusi terhadap kesakitan. Keadaan gizi yang buruk akan mempermudah seseorang untuk terkena penyakit-penyakit infeksi. Sebaliknya, penyakit infeksi akan memperburuk keadaan status gizi seseorang. Interaksi antara penyebab infeksi dan kurang energi protein merupakan penyebab utama terjadinya penyakit, hal ini sering terjadi secara bersamaan dan antara satu dengan yang lainnya saling mempengaruhi. Malnutrisi merupakan masalah ekologi yang merupakan hasil akhir dari interaksi multifaktor dari lingkunga fisik, biologi, sosial, ekonomi, politik dan budaya. Aspek kesehatan yang berpengaruh besar terhadap status gizi masyarakat adalah kontribusi infeksi, sanitasi lingkungan, pelayanan kesehatan. Infeksi dapat menyebabkan kurangnya nafsu makan sehingga menyebabkan asupan makanan menjadi rendah yang akhirnya menyebabkan kurang gizi dan sanitasi lingkungan yang buruk seperti air minum tidak bersih, tidak adanya penampungan air limbah, tidak menggunakan kloset yang baik juga kepadatan penduduk yang tinggi dapat menyebabkan penyebaran penyakit. 6

Munculnya permasalahan gizi dapat dilihat dari ketidak-seimbangan antara penjamu, agen dan lingkungan. Unsur penjamu meliputi: faktor genetik, umur, jenis kelamin, kelompok etnik, keadaan fisiologis, keadaan imunologis dan kebiasaan seseorang. Unsur sumber penyakit (agens) meliputi faktor gizi, kimia dari luar, kimia dari dalam, faali/fisiologi, genetik, psikis, tenaga/kekuatan fisik dan biologis/parasit. Unsur lingkungan meliputi tiga faktor yaitu lingkungan fisik, lingkungan biologis dan lingkungan sosial ekonomi dan budaya. Proses riwayat alamiah terjadinya penyakit yang diterapkan pada masalah gizi (gizi kurang) melalui berbagai tahap yaitu diawali dengan terjadinya interaksi antara penjamu, sumber penyakit dan lingkungan. ${ }^{7}$

Dalam review Achmadi (2006) menunjukkan kelompok agen penyakit yang disebut sebagai mikroorganisme yang mampu menimbulkan gangguan penyakit khususnya penyakit menular dan komponen lingkungan sebagai media transmisi penyakit. Penyakit berbasis lingkungan didefinisikan sebagai ilmu yang mempelajari proses kejadian atau fenomena penyakit yang terjadi pada sebuah kelompok masyarakat, yang berhubungan, berakar (bounded) atau memiliki keterkaitan erat dengan satu atau lebih komponen lingkungan pada sebuah ruang dalam masyarakat tersebut bertempat tinggal atau beraktivitas dalam jangka waktu tertentu. Penyakit tersebut bisa dicegah atau dikendalikan, kalau kondisi lingkungan yang berhubungan atau diduga berhubungan dengan penyakit tersebut dihilangkan. ${ }^{8}$ Pada rumah tangga yang tidak punya cukup makanan dan hidup dalam lingkungan yang memungkinkan diare, serta berbagai penyakit lain biasa terjadi, anak sangat rentan terhadap gizi kurang. Risiko meningkat pada saat diare dan penyakit lain, semakin mengurangi asupan protein, mineral dan zat gizi lain yang dibutuhkan anak agar tetap sehat. Pada waktu anak jatuh sakit, mereka kehilangan tenaga dan berbagai zat gizi lainnya dengan cepat serta menyebabkan hidup mereka menjadi lebih berisiko dibanding orang dewasa. ${ }^{4}$ 
Penelitian lanjutan ini bertujuan untuk mengetahui hubungan antara penyakit menular berbasis lingkungan dengan status gizi balita $(0-$ 59 bulan) dengan menggunakan data Riskesdas 2007.

\section{METODE PENELITIAN}

Penelitian ini merupakan analisis lanjut dari data Riset Kesehatan Dasar (Riskesdas) tahun 2007 yang dilaksanakan oleh Badan Litbangkes RI. Desain penelitian adalah cross-sectional yang bersifat deskriptif. Populasi penelitian adalah seluruh balita 0-59 bulan pada Riskesdas 2007, sedangkan sampel adalah seluruh balita 0-59 bulan pada Riskesdas 2007dengan ibu yang berusia 15-54 tahun. Kriteria inklusi seluruh rumah tangga Riskesdas 2007 yang mempunyai balita dengan variabel yang lengkap.

Data yang dikumpulkan meliputi: karakteristik balita (umur, jenis kelamin, berat badan), karakteristik ibu (umur, pendidikan, dan pekerjaan), penyakit menular berbasis lingkungan (penyakit filariasis, demam berdarah dengue, malaria, infeksi saluran pernafasan akut, pneumonia, tuberkulosis paru, campak, tifoid, hepatitis, diare), dan lingkungan rumah tangga balita (kualitas fisik air minum, kualitas tanah, dan pemeliharaan ternak).

Status gizi balita (BB/U) dihitung menggunakan software anthro 2007 dengan katagori: gizi lebih, gizi baik, gizi kurang, dan gizi buruk. ${ }^{9}$ Selanjutnya untuk data penyakit menular berbasis lingkungan, dikatakan sakit bila didiagnosis oleh petugas kesehatan menderita salah satu atau lebih penyakit menular berbasis lingkungan yaitu penyakit filariasis, demam berdarah dengue, malaria, infeksi saluran pernafasan akut, pneumonia, tuberkulosis paru, campak, tifoid, hepatitis dan diare. Sedangkan untuk penilaian kualias lingkungan rumah tangga diukur menurut masing-masing variabel. Kualitas air minum dikatakan baik bila dalam pemeriksaan fisik menunjukkan jernih, tidak berbau, tidak berasa, tidak berbusa. Kualitas tanah dikatakan baik bila tempat saluran pembuangan air limbah dari kamar mandi/tempat cuci/dapur di penampungan tertutup di pekarangan dan tempat pembuangan sampah di luar rumah tertutup. Sedangkan pemeliharaan hewan ternak dikatakan baik bila memelihara hewan ternak di luar rumah.

Selanjutnya tahapan analisis data meliputi: analisis univariat, yaitu untuk melihat distribusi frekuensi penyakit menular berbasis lingkungan, status gizi balita, karakteristik balita, karakteristik ibu balita dan faktor lingkungan. Analisis bivariat, yaitu untuk melihat distribusi frekuensi status gizi balita menurut, penyakit menular berbasis lingkungan, karakteristik balita, karakteristik ibu balita dan faktor lingkungan. Kemudian analisis multivariat, yaitu untuk mengidentifikasi hubungan antara penyakit menular berbasis lingkungan dengan status gizi balita (0-59 bulan) setelah dikontrol oleh variabel karakteristik balita, karakteristik ibu, dan faktor lingkungan. Semua tahapan analisis data menggunakan perangkat lunak komputer.

\section{HASIL}

\section{Penyakit Infeksi dan Status Gizi}

Pada Tabel 1 menunjukkan proporsi balita menurut kejadian penyakit menular berbasis lingkungan dan status gizi. Proporsi balita yang sakit sebesar 28,2 persen dan proporsi status gizi lebih $(3,0 \%)$; gizi baik $(77,4 \%)$; gizi kurang $(14,3 \%)$ dan gizi buruk $(5,3 \%)$.

Tabel 1

Distribusi Balita menurut Kejadian Penyakit Infeksi dan Status Gizi

\begin{tabular}{llrr}
\hline Penyakit Infeksi dan Status Gizi & $\mathrm{n}$ & $\%$ \\
\hline Penyakit Infeksi & Sakit & 15860 & 28,2 \\
& Tidak & 40335 & 71,8 \\
\hline Status Gizi (BB/U) & Gizi lebih & 1674 & 3,0 \\
& Gizi baik & 43468 & 77,4 \\
& Gizi kurang & 8059 & 14,3 \\
& Gizi buruk & 2994 & 5,3 \\
\hline & Jumlah & 56195 & 100,0 \\
\hline
\end{tabular}




\section{Karakteristik Balita}

Karakteristik balita secara rinci dapat dilihat pada Tabel 2. Proporsi balita di perdesaan tampak lebih banyak daripada di perkotaan. Kemudian proporsi menurut jenis kelamin hampir tidak berbeda antara laki-laki dan perempuan. Selanjutnya menurut kelompok umur tampak bahwa kelompok umur balita 2459 bulan lebih banyak dibandingkan kelompok umur di bawahnya.

Tabel 2

Karakteristik Balita menurut Tempat Tinggal, Jenis kelamin, dan Kelompok Umur

\begin{tabular}{llrr}
\hline Karaktristik Balita & & $\mathrm{n}$ & $\%$ \\
\hline Tempat Tinggal & Perdesaan & 35994 & 64,1 \\
& Perkotaan & 20201 & 35,9 \\
\hline \multirow{2}{*}{ Jenis Kelamin } & Laki-laki & 28740 & 51,1 \\
& Perempuan & 27455 & 48,9 \\
\hline Kelompok Umur & 0-11 bulan & 8461 & 15,1 \\
& 12-23 bulan & 9579 & 17,0 \\
& 24-59 bulan & 38155 & 67,9 \\
\hline & Jumlah & 56195 & 100,0 \\
\hline
\end{tabular}

\section{Karakteristik Ibu Balita}

Pada Tabel 3 menunjukkan proporsi ibu balita menurut umur, pendidikan dan pekerjaan. Proporsi terbanyak untuk umur ibu balita terdapat pada kelompok umur 20-35 tahun yaitu sebesar 72,6 persen; pendidikan ibu balita pada tingkat SD ke bawah, yaitu sebesar 51,9 persen dan pekerjaan ibu balita tidak bekerja sebesar 68,9 persen.

Tabel 3

Karakteristik Ibu Balita menurut Umur, Pendidikan dan Pekerjaan

\begin{tabular}{llrr}
\hline \multicolumn{2}{l}{ Karakteristik ibu } & $\mathrm{n}$ & $\%$ \\
\hline Umur & 20-35 th & 40790 & 72,6 \\
& $<$ 20th dan $>35$ th & 15405 & 27,4 \\
\hline \multirow{4}{*}{ Pendidikan } & SD ke bawah & 29172 & 51,9 \\
& SMP & 11378 & 20,3 \\
& SMA & 12442 & 22,1 \\
& Perguruan Tinggi & 3203 & 5,7 \\
\hline Pekerjaan & Tidak bekerja & 38744 & 68,9 \\
& Bekerja & 17451 & 31,1 \\
\hline & Jumlah & 56195 & 100,0 \\
\hline
\end{tabular}

\section{Karakteristik Lingkungan Rumah Tangga}

Gambaran karaktristik lingkungan rumah tangga dapat dilihat pada Tabel 4. Proporsi kualitas air dengan katagori kurang masih terdapat sebesar 14,5 persen. Proporsi kualitas tanah menunjukkan sebesar 5,4 persen masih dalam katagori kurang. Sedangkan pemeliharaan ternak yang kurang memenuhi syarat kesehatan sebesar 6,3 persen. 
Tabel 4

Karakteristik Lingkungan Rumah Tangga Sampel menurut Kualitas air, Kualitas Tanah, dan Pemeliharan Ternak

\begin{tabular}{llrr}
\hline Karakteristik Lingkungan & & $\mathrm{n}$ & $\%$ \\
\hline Kualitas air & Kurang & 8131 & 14,5 \\
& Baik & 48064 & 85,5 \\
\hline Kualitas Tanah & Kurang & 3020 & 5.4 \\
& Baik & 53175 & 94.6 \\
\hline Pemeliharaan Ternak & Kurang & 3531 & 6.3 \\
& Baik & 52664 & 93.7 \\
\hline & Jumlah & 56195 & 100.0 \\
\hline
\end{tabular}

Status Gizi (BB/U) menurut Karakteristik Balita

Tabel 5 menunjukkan proporsi status gizi balita $(\mathrm{BB} / \mathrm{U})$ menurut tempat tinggal, jenis kelamin, dan kelompok umur. Menurut tempat tinggal, proporsi balita dengan gizi baik dan gizi lebih di perdesaan lebih kecil dibandingkan perkotaan. Balita dengan status gizi baik di perdesaan $(75,6 \%)$ dan perkotaan $(3,6 \%)$ sedangkan balita dengan status gizi lebih di perdesaan $(2,6 \%)$ dan perkotaan $(3,6 \%))$. Selanjutnya proporsi balita dengan status gizi kurang dan buruk lebih banyak yang tinggal di perdesaan dibandingkan di perkotaan.

Menurut jenis kelamin, proporsi balita dengan status gizi kurang dan buruk pada laki- laki lebih tinggi dibandingkan pada perempuan. Proporsi balita dengan status gizi kurang pada laki-laki $(15 \%)$ dan perempuan $(13,7 \%)$ sedangkan balita dengan status gizi buruk pada laki-laki $(5,7 \%)$ dan perempuan $(5,0 \%)$.

Berdasarkan kelompok umur, proporsi balita dengan satus gizi lebih baik semakin meningkat sesuai dengan pertambahan umur dimana untuk gizi lebih (0-11 bulan (2,2\%), 12 23 bulan $(3,9 \%)$ dan $24-59$ bulan $(5,2 \%)$ sedangkan untuk proporsi gizi kurang dan buruk semakin menurun sesuai dengan pertambahan umur untuk status gizi kurang (0-11 bulan $(16,7 \%), 12-23$ bulan $(11,4 \%)$ dan $24-59$ bulan $(6,9 \%)$ dan status gizi buruk ( $0-11$ bulan $(6,3 \%)$, $12-23$ bulan $(3,6 \%)$ dan $24-59$ bulan $(3,0 \%)$.

Tabel 5

Distribusi Status Gizi Balita (BB/U) menurut Karakteristik Balita

\begin{tabular}{|c|c|c|c|c|c|c|c|c|c|c|c|}
\hline \multirow{3}{*}{ Karakteristik Balit } & & \multicolumn{10}{|c|}{ Status Gizi (BB/U) } \\
\hline & & \multicolumn{2}{|c|}{ lebih } & \multicolumn{2}{|c|}{ baik } & \multicolumn{2}{|c|}{ kurang } & \multicolumn{2}{|c|}{ buruk } & \multicolumn{2}{|c|}{ Jumlah } \\
\hline & & $\mathrm{n}$ & $\%$ & $\mathrm{n}$ & $\%$ & $n$ & $\%$ & $\mathrm{n}$ & $\%$ & $n$ & $\%$ \\
\hline \multirow[t]{2}{*}{ Tempat tinggal } & Perdesaan & 945 & 2,6 & 27224 & 75,6 & 5565 & 15,5 & 2260 & 6,3 & 35994 & 100,0 \\
\hline & Perkotaan & 729 & 3,6 & 16244 & 80,4 & 2494 & 12,3 & 734 & 3,6 & 20201 & 100,0 \\
\hline \multirow[t]{2}{*}{ Jenis kelamin } & Laki-laki & 918 & 3,2 & 21881 & 76,1 & 4308 & 15,0 & 1633 & 5,7 & 28740 & 100,0 \\
\hline & Perempuan & 756 & 2,8 & 21587 & 78,6 & 3751 & 13,7 & 1361 & 5,0 & 27455 & 100,0 \\
\hline \multirow[t]{4}{*}{ Kelompok umur } & $0-11 \mathrm{bln}$ & 858 & 2,2 & 28528 & 74,8 & 6375 & 16,7 & 2394 & 6,3 & 38155 & 100,0 \\
\hline & $12-23 \mathrm{bln}$ & 373 & 3,9 & 7762 & 81,0 & 1096 & 11,4 & 348 & 3,6 & 9579 & 100,0 \\
\hline & $24-59 \mathrm{bln}$ & 443 & 5,2 & 7178 & 84,8 & 588 & 6,9 & 252 & 3,0 & 8461 & 100,0 \\
\hline & Jumlah & 1674 & 3,0 & 43468 & 77,4 & 8059 & 14,3 & 2994 & 5,3 & 56195 & 100,0 \\
\hline
\end{tabular}


Status Gizi (BB/U) menurut Penyakit Menular Berbasis Lingkungan

Menurut kejadian penyakit menular berbasis lingkungan, proporsi balita dengan status gizi kurang dan status gizi buruk yang menderita sakit masing-masing sebesar 15,8 persen dan 5,7 persen (Tabel 6).

Tabel 6

Distribusi Status Gizi Balita (BB/U) menurut Penyakit Berbasis Lingkungan

\begin{tabular}{|c|c|c|c|c|c|c|c|c|c|c|}
\hline \multirow{3}{*}{$\begin{array}{l}\text { Penyakit berbasis } \\
\text { lingkungan }\end{array}$} & \multicolumn{10}{|c|}{ Status Gizi (BB/U) } \\
\hline & \multicolumn{2}{|c|}{ Lebih } & \multicolumn{2}{|c|}{ Baik } & \multicolumn{2}{|c|}{ Kurang } & \multicolumn{2}{|c|}{ Buruk } & \multicolumn{2}{|c|}{ Jumlah } \\
\hline & $n$ & $\%$ & $\mathrm{n}$ & $\%$ & $\mathrm{n}$ & $\%$ & $\mathrm{n}$ & $\%$ & $n$ & $\%$ \\
\hline Sakit & 396 & 2,5 & 12050 & 76,0 & 2507 & 15,8 & 907 & 5,7 & 15860 & 100,0 \\
\hline Tidak & 1278 & 3,2 & 31418 & 77,9 & 5552 & 13,8 & 2087 & 5,2 & 40335 & 100,0 \\
\hline Jumlah & 1674 & 3,0 & 43468 & 77,4 & 8059 & 14,3 & 2994 & 5,3 & 56195 & 100,0 \\
\hline
\end{tabular}

\section{Status Gizi Balita (BB/U) menurut Karakteristik Ibu}

Tabel 7 menunjukkan proporsi status gizi balita (BB/U) menurut umur, pendidikan dan pekerjaan ibu balita. Menurut kelompok umur ibu, proporsi balita dengan satus gizi baik dan status gizi lebih cenderung lebih tinggi pada kelompok umur 20-35 tahun dibandingkan umur $<20$ tahun dan $>35$ tahun. Proporsi balita dengan status gizi baik pada kelompok umur 20-35 tahun $(77,5 \%)$ dan kelompok umur kurang dari 20 tahun dan lebih dari 35 tahun

$(2,9 \%)$, sedangkan proporsi balita dengan status gizi lebih pada kelompok umur 20-35 tahun $(3,0 \%)$ dan kelompok umur kurang dari 20 tahun dan lebih dari 35 tahun (2,9\%). Selanjutnya proporsi balita dengan satus gizi kurang dan buruk pada ibu kelompok umur 2035 tahun lebih kecil dibandingkan kelompok umur kurang dari 20 tahun dan lebih dari 35 tahun.

Tabel 7

Distribusi Status Gizi Balita (BB/U) menurut Karakteristik Ibu

\begin{tabular}{|c|c|c|c|c|c|c|c|c|c|c|}
\hline \multirow{3}{*}{ Karakteristik Ibu } & \multicolumn{10}{|c|}{ Status Gizi Balita (BB/U) } \\
\hline & \multicolumn{2}{|c|}{ lebih } & \multicolumn{2}{|c|}{ baik } & \multicolumn{2}{|c|}{ kurang } & \multicolumn{2}{|c|}{ buruk } & \multicolumn{2}{|c|}{ Jumlah } \\
\hline & $\mathrm{n}$ & $\%$ & $\mathrm{n}$ & $\%$ & $\mathrm{n}$ & $\%$ & $n$ & $\%$ & $n$ & $\%$ \\
\hline \multicolumn{11}{|l|}{ Kelompok Umur } \\
\hline $20-35$ th & 1223 & 3,0 & 31610 & 77,5 & 5805 & 14,2 & 2152 & 5,3 & 40790 & 100,0 \\
\hline$<20$ th dan $>35$ th & 451 & 2,9 & 11858 & 77,0 & 2254 & 14,6 & 842 & 5,5 & 15405 & 100,0 \\
\hline \multicolumn{11}{|l|}{ Pendidikan } \\
\hline SD ke bawah & 666 & 2,3 & 21863 & 74,9 & 4708 & 16,1 & 1935 & 6,6 & 29172 & 100,0 \\
\hline SMP & 365 & 3,2 & 8863 & 77,9 & 1602 & 14,1 & 548 & 4,8 & 11378 & 100,0 \\
\hline SMA & 468 & 3,8 & 10077 & 81,0 & 1466 & 11,8 & 431 & 3,5 & 12442 & 100,0 \\
\hline PT & 175 & 5,5 & 2665 & 83,2 & 283 & 8,8 & 80 & 2,5 & 3203 & 100,0 \\
\hline \multicolumn{11}{|l|}{ Pekerjaan } \\
\hline Tidak bekerja & 1113 & 2,9 & 30031 & 77,5 & 5568 & 14,4 & 2032 & 5,2 & 38744 & 100,0 \\
\hline Bekerja & 561 & 3,2 & 13437 & 77,0 & 2491 & 14,3 & 962 & 5,5 & 17451 & 100,0 \\
\hline Jumlah & 1674 & 3,0 & 43468 & 77,4 & 8059 & 14,3 & 2994 & 5,3 & 56195 & 100,0 \\
\hline
\end{tabular}


Dilihat dari pendidikan ibu balita, proporsi balita satus gizi baik dan status gizi lebih cenderung meningkat sesuai dengan tingkat pendidikan ibu. Proporsi balita dengan status gizi baik pada ibu dengan pendidikan SD kebawah $(74,9 \%)$, SMP $(77,9 \%)$, SMA $(81,0 \%)$ dan PT $(83,2 \%)$. Proporsi balita dengan status gizi lebih pada iu dengan pendidikan SD ke bawah $(2,3 \%)$, SMP $(3,2 \%)$, SMA $(3,8 \%)$ dan PT $(5,5 \%))$. Sedangkan proporsi balita satus gizi kurang dan buruk cenderung menurun sesuai dengan tingkat pendidikan ibu. Proporsi balita dengan status gizi kurang pada ibu dengan pendidikan SD ke bawah $(16,1 \%)$, SMP $(14,1 \%)$, SMA $(11,8 \%)$ dan PT $(8,8 \%)$. Proporsi balita dengan status gizi buruk pada ibu dengan pendidikan SD ke bawah $(6,6 \%)$, SMP $(4,8 \%)$, SMA $(3,5 \%)$ dan PT $(2,5 \%)$.

Selanjutnya menurut pekerjaan ibu balita, proporsi balita dengan status gizi buruk pada ibu balita yang tidak bekerja lebih kecil dibandingkan dengan yang bekerja. Proporsi balita dengan status gizi buruk pada ibu yang tidak bekerja sebesar 5,2 persen dan pada ibu yang bekerja sebesar 5,5 persen.

\section{Status Gizi Balita (BB/U) menurut Karakteristik Lingkungan}

Gambaran status gizi balita (BB/U) menurut karakteristik lingkungan secara rinci dijelaskan di Tabel 8. Proporsi balita dengan status gizi kurang dan status gizi buruk cenderung lebih tinggi pada rumah tangga dengan kualitas air yang kurang baik. Hal yang sama juga tampak pada proporsi balita dengan status gizi kurang dan buruk yang lebih banyak terjadi pada rumah tangga dengan kualitas tanah yang kurang baik. Selanjutnya menurut rumah tangga yang memelihara hewan ternak, juga menunjukkan bahwa proporsi balita dengan status gizi kurang dan buruk cenderung lebih tinggi pada rumah tangga yang memelihara hewan ternak di dalam rumah.

Tabel 8

Distribusi Status Gizi Balita (BB/U) menurut Karakteristik Lingkungan

\begin{tabular}{|c|c|c|c|c|c|c|c|c|c|c|c|}
\hline \multirow{2}{*}{\multicolumn{2}{|c|}{ Karakteristik lingkungan }} & \multicolumn{10}{|c|}{ Status Gizi (BB/U) } \\
\hline & & \multicolumn{2}{|c|}{ Lebih } & \multicolumn{2}{|c|}{ Baik } & \multicolumn{2}{|c|}{ Kurang } & \multicolumn{2}{|c|}{ Buruk } & \multicolumn{2}{|c|}{ Jumlah } \\
\hline & & $n$ & $\%$ & $\mathrm{n}$ & $\%$ & $\mathrm{n}$ & $\%$ & $\mathrm{n}$ & $\%$ & $n$ & $\%$ \\
\hline \multirow[t]{2}{*}{ Kualitas air } & Kurang & 221 & 2,7 & 6107 & 75,1 & 1291 & 15,9 & 512 & 6,3 & 8131 & 100,0 \\
\hline & Baik & 1453 & 3,0 & 37361 & 77,7 & 6768 & 14,1 & 2482 & 5,2 & 48064 & 100,0 \\
\hline \multirow[t]{2}{*}{ Kualitas tanah } & Kurang & 1536 & 2,9 & 41009 & 77,1 & 7736 & 14,5 & 2894 & 5,4 & 53175 & 100,0 \\
\hline & Baik & 138 & 4,6 & 2459 & 81,4 & 323 & 10,7 & 100 & 3,3 & 3020 & 100,0 \\
\hline \multirow{3}{*}{$\begin{array}{l}\text { Pemeliharaan } \\
\text { ternak }\end{array}$} & Kurang & 106 & 3,0 & 2675 & 75,8 & 544 & 15,4 & 206 & 5,8 & 3531 & 100,0 \\
\hline & Baik & 1568 & 3,0 & 40793 & 77,8 & 7515 & 14,3 & 2788 & 5,3 & 52664 & 100,0 \\
\hline & Jumlah & 1674 & 3,0 & 43468 & 77,4 & 8059 & 14,3 & 2994 & 5,3 & 56195 & 100,0 \\
\hline
\end{tabular}

Pemodelan Hubungan Penyakit Menular Berbasis Lingkungan dengan Status Gizi Balita

Langkah pemodelan diawali dengan mengikutsertakan semua potential confounder dan effect modifier dan selanjutnya dilakukan eliminasi effect modifier. Tahap pertama mengevaluasi variabel kovariat yang masuk dalam model, yaitu dengan melihat hasil $p$ value dari masing-masing variabel terkait dengan status gizi balita. Dari hasil analisis bivariate diketahui bahwa semua kovariat memenuhi persyaratan dalam analisis multivariate $(p$ value $<0,25$ ). Hasil analisis regresi logistik hubungan penyakit menular berbasis lingkungan dengan status gizi balita dapat dilihat pada Tabel 9.

Dari pemodelan akhir tersebut di atas dapat dijelaskan bahwa setelah dikontrol confounder variables (karakteristik balita, karakteristik ibu, faktor lingkungan) diketahui bahwa risiko kejadian status gizi kurang dan status gizi buruk pada balita berbeda menurut pendidikan ibu dan tempat tinggal. Dari variabel pendidikan ibu diketahui bahwa risiko status gizi kurang dan status gizi buruk pada balita yang mengalami penyakit menular berbasis lingkungan dan ibu dengan pendidikan SD ke bawah $(\mathrm{OR}=2,05)$ 
dibandingkan ibu dengan pendidikan perguruan tinggi $(\mathrm{OR}=1,12)$. Sedangkan menurut tempat tinggal diketahui bahwa risiko status gizi kurang dan status gizi buruk pada balita yang mengalami penyakit menular berbasis lingkungan dan bertempat tinggal di perdesaan $(\mathrm{OR}=1,25)$ dibandingkan balita yang tinggal di perkotaan $(\mathrm{OR}=1,12)$. Selanjutnya dapat diketahui nilai koefisien dari masing-masing variabel seperti terlihat pada Tabel 10.

Tabel 9

Hubungan Penyakit Menular Berbasis Lingkungan dengan Status Gizi Balita

\begin{tabular}{lcc}
\hline Variabel & Odds Ratio & Cl: $95 \%$ \\
\hline Penyakit MenularPendidikan & & \\
$\circ \quad$ Penyakit Menular | PT & 1,12 & $1,06-1,17$ \\
$\circ \quad$ Penyakit Menular | SMA & 1,37 & $1,22-1,55$ \\
$\circ \quad$ Penyakit Menular | SMP & 1,69 & $1,50-1,90$ \\
$\circ \quad$ Penyakit Menular | SD ke bawah & 2,05 & $1,83-2,30$ \\
\hline Penyakit Menular*Tempat Tinggal & & \\
$\circ \quad$ Penyakit Menular | Perkotaan & 1,12 & $1,06-1,17$ \\
$\circ \quad$ Penyakit Menular | Perdesaan & 1,25 & $1,19-1,32$ \\
\hline
\end{tabular}

Tabel 10

Nilai Koefisien Beta, Standar error, Nilai z, dan Nilai p

Model Akhir Hubungan Penyakit Menular Berbasis Lingkungan dengan Status Gizi Balita (BB/U)

\begin{tabular}{lrrrrr}
\hline Variabel & \multicolumn{1}{c}{ B } & Standar Error & \multicolumn{1}{c}{$\mathrm{z}$} & $\mathrm{P}>|\mathrm{z}|$ & \multicolumn{1}{c}{$\mathrm{Cl}: 95 \%$} \\
\hline Penyakit Menular & 0.1099942 & 0.0233235 & 4,72 & 0,000 & $0,064-1,168$ \\
Pendidikan lbu & & & & & \\
$\quad$ - Perguruan Tinggi & ref & & & & \\
$\quad$ - SMA & 0.3186477 & 0.0611548 & 5,21 & 0,000 & $0,198-0,438$ \\
$\quad$ - SMP & 0.526506 & 0.0611527 & 8,61 & 0,000 & $0,406-0,646$ \\
$\quad$ - SD ke bawah & 0.7190969 & 0.058604 & 12,27 & 0,000 & $0,604-0,833$ \\
Tempat Tinggal & & & & & \\
$\quad$ - Perkotaan & ref & & & & \\
$\quad$ - Perdesaan & 0.2280016 & 0.0245503 & 9,29 & 0,000 & $0,179-0,833$ \\
Konstanta & -2.157605 & 0.0566738 & $-38,07$ & 0,000 & $-2,268--2,046$ \\
\hline
\end{tabular}

\section{BAHASAN}

Penelitian ini menggunakan data sekunder Riskesdas 2007 yang beberapa masih memiliki keterbatasan. Data lingkungan masih terbatas pada kualitas air, kualitas tanah, dan hewan peliharaan di rumah tangga yang belum digali secara maksimal. Selain itu hubungan antara penyakit menular berbasis lingkungan dengan status gizi dimungkinkan juga merupakan hubungan yang timbal balik, sehingga dimungkinkan terjadinya bias dalam hubungan keduanya. ${ }^{10}$
Hasil penelitian ini menunjukkan adanya hubungan antara penyakit menular berbasis lingkungan dengan status gizi balita (BB/U) menurut tingkat pendidikan ibu dan tempat tinggal setelah dikontrol confounder variables (karakteristik balita, karakteristik ibu, faktor lingkungan). Adanya kecenderungan peningkatan risiko status gizi kurang dan status gizi buruk pada balita yang mengalami penyakit menular berbasis lingkungan dengan ibu yang tingkat pendidikannya semakin rendah. Hal ini kemungkinan terkait dengan pola asuh anak. Pola asuh meliputi 6 hal, yaitu perhatian dan 
dukungan ibu terhadap anak, pemberian ASI atau makanan pendamping pada anak, rangsangan psikososial pada anak, persiapan dan penyimpanan makanan, praktek kebersihan dan sanitasi lingkungan, dan perawatan anak dalam keadaan sakit seperti mencari pelayanan kesehatan. ${ }^{11}$

Apabila ibu memiliki pengetahuan yang tinggi maka akan lebih aktif dalam mencari informasi untuk meningkatkan pengetahuan dan keterampilan dalam pengasuhan anak. Secara positif ibu yang tidak bekerja memiliki waktu lebih banyak untuk diberikan dalam mengasuh anak. Kebutuhan balita akan asuh meliputi kebutuhan akan gizi yang adekuat, perawatan kesehatan dasar, keadaan tempat tinggal yang layak, dan sandang. ${ }^{12}$

Hasil penelitian juga menunjukkan adanya kecenderungan peningkatan risiko status gizi kurang dan status gizi buruk pada balita yang mengalami penyakit menular berbasis lingkungan yang bertempat tinggal di perdesaan dibandingkan balita yang tinggal di perkotaan. Kemungkinan hal ini terkait dengan sarana dan prasarana kesehatan di perdesaan yang masih rendah dibandingkan di perkotaan. Jika dilihat dari pencapaian MDG's Indonesia 2007 terkait dengan pelayanan sanitasi pada tahun 2007 pelayanan sanitasi yang aman di perkotaan mencapai 81,8 persen, sedangkan di perdesaan sebesar 60 persen, atau secara keseluruhan mencapai 69,3 persen. Dengan demikian secara keseluruhan 30,7 persen penduduk tanpa akses sanitasi yang layak, yang berarti ada 72,5 juta penduduk dengan akses sanitasi yang buruk, membuang kotoran di luar rumah, dan sebagainya..$^{13} \mathrm{Hal}$ ini menunjukkan kondisi yang belum menggembirakan, karena ketersediaan pelayanan sanitasi yang aman merupakan kebutuhan dasar masyarakat yang harus dipenuhi dan terkait erat dengan aspekaspek lain seperti kesehatan dan kemiskinan. Selain itu sanitasi belum merupakan prioritas bagi banyak pemerintah daerah dalam penyediaan pelayanannya. ${ }^{14}$

Pelayanan sanitasi yang masih kurang di perdesaan menjadikan lingkungan menjadi media transmisi penyakit sehingga dapat menyebabkan terjadinya penyakit-penyakit menular berbasis lingkungan. Secara deskriptif penyakit menular berbasis lingkungan dapat menyebabkan kejadian gizi kurang dan menunjukkan hubungan yang bermakna, hal inibisa terjadi karena pada kondisi sakit dapat terjadi malnutrisi karena nutrisi seorang yang sakit diperparah dengan diare, malabsorpsi, kehilangan nafsu makan, pengalihan nutrisi untuk respon kekebalan tubuh, dan kehilangan nitrogen urin, yang semuanya menyebabkan kehilangan unsur hara dan kerusakan lebih lanjut untuk mekanisme pertahanan. Ini, pada gilirannya, menyebabkan berkurangnya asupan makanan. Selain daripada itu, demam meningkatkan energi dan kebutuhan mikronutrien. ${ }^{12}$

Dengan demikian diperlukan upaya-upaya dan kebijakan pangan dan gizi untuk memecahkan masalah gizi kurang dalam jangka pendek dan jangka panjang. Pemilihan program gizi yang melibatkan lintas program maupun lintas sektor sangat diharapkan dengan prioritas di level perdesaan. Penyuluhan gizi, evaluasi program gizi yang ada, pemilihan intervensi yang dilakukan harus sesuai dengan masalah yang jumpai. ${ }^{15}$ Program penyuluhan gizi dan kesehatan diharapkan dapat meningkatkan pengetahuan ibu balita sehingga orang tua balita diharapkan memahami pentingnya makanan dan gizi , sehingga mau bersikap dan bertindak mengikuti norma-norama gizi. ${ }^{16}$

\section{SIMPULAN DAN SARAN}

\section{Simpulan}

Risiko status gizi kurang dan status gizi buruk pada balita lebih tinggi pada balita dengan ibu yang berpendidikan SD ke bawah yang anaknya mengalami penyakit menular berbasis lingkungan $(\mathrm{OR}=2,05)$. Di samping itu risiko status gizi kurang dan status gizi buruk pada balita juga lebih tinggi pada balita yang bertempat tinggal di perdesaan yang mengalami penyakit menular berbasis lingkungan $(\mathrm{OR}=1,25)$.

\section{Saran}

Upaya penanggulangan masalah gizi kurang dan gizi buruk di perdesaan diharapkan menjadi prioritas program gizi di tingkat kabupaten, seperti dengan program penyuluhan gizi kepada ibu balita, sehingga diharapkan adanya peningkatan pengetahuan dan pengasuhan ibu terhadap balita. 


\section{UCAPAN TERIMA KASIH}

Kami menyampaikan ucapan terimakasih kepada Kepala Badan Penelitian dan Pengembangan Kesehatan Republik Indonesia yang telah memberikan kesempatan untuk melakukan analisis data Riset Kesehatan Dasar tahun 2007.

\section{RUJUKAN}

1. Kementerian Kesehatan RI. Rencana Strategis Kementerian Kesehatan RI Tahun 2010 - 2014. Jakarta: Kementerian Kesehatan; 2010.

2. Departemen Kesehatan RI. Laporan Hasil Riset Kesehatan Dasar (Riskesdas) tahun 2007. Jakarta: Badan Penelitian dan Pengembangan Kesehatan Rl; 2008.

3. Departemen Kesehatan RI. Laporan Hasil Riset Kesehatan Dasar (Riskesdas) tahun 2010. Jakarta: Badan Penelitian dan Pengembangan Kesehatan Rl; 2010.

4. Kementerian Kesehatan Republik Indonesia. Penuntun Hidup Sehat. Jakarta: Unicef Indonesi; 2010.

5. Santoso S, Ranti AL. Kesehatan dan Gizi. Jakarta:Rineka Cipta; 1999.

6. FKM Universitas Indonesia. Gizi dan Kesehatan Masyarakat. Jakarta: Rajawali Press; 2010.

7. Supariasa IDN, Bakri B,Fajar I. Penilaian Status Gizi. Jakarta: Penerbit Buku Kedokteran EGC; 2002.
8. Achmadi UF. Dasar-dasar Penyakit Berbasis Lingkungan. Jakarta: Rajawali Pers; 2012.

9. WHO. WHO Anthro Plus for Personal Computers Manual. Geneve: WHO; 2009.

10. Katona $P$, Katona J. The interaction between nutrition and infection. 2008. cid.oxfordjournals.org/content/46/10/1582.f ull

11. Sunarwati. Praktek Pengasuhan dalam menyiapkan Anak Berkualitas. 2009. http://nurulfikri.sch.id/index.php.

12. Kirana. Hubungan antara tingkat pengetahuan dan pola asuh ibu dengan. status gizi balita di Kelurahan Antirogo. alumni.unair.ac.id/kumpulanfile/110558430 56_abs.pdf

13. BAPENAS. Studi kebijakan pengembangan anak usia dini yang holistic dan terintegrasi. Jakarta: Bappenas; 2006

14. Abang AT. Hubungan sanitasi lingkungan dan penyakit infeksi dengan status gizi anak balita di Kecamatan Tenggarong Kabupaten Kutai. 2012. etd.ugm.ac.id/index.php?

15. Behrman. Kliegman. IImu Kesehatan Anak. Jakarta: Penerbit Buku Kedokteran EGC; 2000.

16. Suhardjo. Perencanaan Pangan dan Gizi.Jakarta: Bumi Aksara; 2003. 